\title{
Kwestia homoseksualizmu w Listach Powszechnych i w Apokalipsie św. Jana
}

\author{
The Issue of Homosexuality in the Catholic Letters and the Book of Revelation
}

\section{DOROTA MUSZYTOWSKA}

Uniwersytet Kardynała Stefana Wyszyńskiego w Warszawie

d.muszytowska@uksw.edu.pl, ORCID: 0000-0001-5873-382X

\begin{abstract}
Streszczenie: W dyskusji nad tematyką homoseksualności i biblijnego nauczania w tej kwestii przywoływane są teksty z Listu św. Judy 7 i Drugiego Listu św. Piotra 2,6 oraz Apokalipsy św. Jana 22,15. Ze względu na to, że żaden z tych tekstów nie podejmuje bezpośrednio zagadnień związanych z moralną oceną homoseksualności, zarzuca się często, że są one nadinterpretowane i wykorzystywane w nieuzasadniony sposób w nauczaniu. W niniejszym opracowaniu skoncentrowano się na analizie tych fragmentów, ukazując ich funkcje w argumentacji, w jakiej zostały użyte, ich siłę perswazyjną i teologiczny sens, po to, aby zweryfikować zasadność powoływania się na te teksty w dyskusjach nad homoseksualizmem i jego oceną. Szczegółowe analizy pozwalają postawić wniosek, że żaden z tych utworów nie porusza bezpośrednio tematyki homoseksualizmu. Nie jest także oczywiste, że historycznym i retorycznym kontekstem tych wypowiedzi było podejmowanie przez chrześcijan aktywności homoseksualnej. Dla autorów owych trzech pism kwestia ta nie była istotą ich nauczania. Wszystkie jednak analizowane fragmenty dotyczą, w różnym stopniu, sfery ludzkiej seksualności. Wszelkie akty i zachowania seksualne, które nie są zgodne z wolą Boga, są jednoznacznie negatywnie ocenione i ukazywane jako konsekwencje zaprzeczania autorytetowi władzy Jezusa Chrystusa, prowadzące do bezbożności, oraz jako jako przyczyny utraty łaski zbawienia.
\end{abstract}

Słowa kluczowe: homoseksualizm; rozwiązłość; bezbożność; Sodoma i Gomora; Jud 7; 2 P 2,6; Ap 21,8; Ap 22,15

Abstract: On the discussion of homosexuality and biblical teaching consider the texts from Jude 7 and 2 Peter 2:6 and Revelation 22:15. Because none of these texts directly address issues related to the moral evaluation of homosexuality, it is often accused of being misinterpreted and used in an unjustified way of teaching. This study focuses on analyzing these fragments, to show their functions in those arguments, their persuasive power and theological sense, and to verify the legitimacy of referring to these texts in discussions on homosexuality and its assessment. Detailed analyses allow us to conclude that none of these works deals directly with the topic of homosexuality. It is also not evident that the undertaking of homosexual activity by Christians informed these statements' historical and rhetorical context. For the authors of the three writings, this question was not the essence of their teaching. However, all analyzed fragments concern, to a different extent, the sphere of human sexuality. Any sexual act and behavior that is inconsistent with God's will are negatively evaluated and are depicted as a consequence of denying the authority of Jesus Christ, leading to impiety, and as a cause leading to the loss of the grace of salvation. Keywords: homosexuality; licentiousness; ungodliness; Sodom and Gomorrah; Jude 7; 2 Pet 2:6; Rev 21:8; Rev 22:15

W Listach Powszechnych Nowego Testamentu oraz w Apokalipsie św. Jana nie mamy tekstów, które bezpośrednio podejmowałyby temat homoseksualizmu i jego moralnej oceny tak, jak zagadnienia te rozpatrywane są w innych pismach NT, 
a mianowicie w Liście do Rzymian, Pierwszym Liście do Koryntian i w Pierwszym Liście do Tymoteusza. W historii interpretacji dwóch fragmentów Listów Powszechnych (2 P 2,6-10; Jud 7) oraz kilku passusów w Apokalipsie Janowej (9,2-21; 21,8.27; $22,15)$ można odnotować rozumienie tych tekstów także w perspektywie homoseksualności ${ }^{1}$. W przypadku Listów Powszechnych jednym z powodów zaistnienia takich interpretacji jest pojawiający się w obydwu listach motyw Sodomy i Gomory, który w tradycji chrześcijańskiej wiązany jest również z grzechem stosunków homoseksualnych. Innym powodem jest słownictwo, którym posłużył się autor Apokalipsy, a które swoim zakresem semantycznym obejmuje także zachowania homoseksualne. Żaden z powyższych tekstów nie wypowiada się bezpośrednio na temat homoseksualizmu. Fakt ten stał się głównym argumentem tych, którzy opowiadają się za porzuceniem utrwalonych historycznie interpretacji tychże fragmentów w kluczu homoseksualności. Na tej podstawie postuluje się także zaprzestanie wykorzystywania tych tekstów w argumentacji związanej z nauczaniem na temat zachowań homoseksualnych.

Celem tego opracowania jest ukazanie na podstawie analizy powyższych tekstów funkcji, jaka została im przypisana w kontekstach literackich, w których występują, oraz egzegeza potencjału ich retoryczności. Powyższa analiza ma prowadzić do weryfikacji tezy o zasadności lub braku tejże zasadności w interpretowaniu badanych fragmentów w odniesieniu do oceny zachowań homoseksualnych.

\section{Motyw Sodomy i Gomory w Drugim Liście św. Piotra i Liście św. Judy}

Z motywem Sodomy i Gomory, znanym z Księgi Rodzaju, wiąże się bogactwo treści i znaczeń, które wprowadza epizod zniszczenia Sodomy i okolicznych miast z Rdz 19,1-29. Nazwa "Sodoma” oraz wyrażenie zestawiające nazwy dwóch miast „Sodoma i Gomora” nabrały symbolicznego wymiaru, oznaczając demonstracyjny, pełen pychy, zuchwały grzech i moralny upadek, nie tylko jednostek, lecz i całych społeczności, lub karę w postaci unicestwienia, zagłady, także w wymiarze eschatologicznym, lub też formę ostrzeżenia przed tym, do czego prowadzi odrzucanie Bożych praw. Teksty biblijne sięgające po ów motyw (np.: Pwt 29,23; Iz 1,9-10; Jer 23,14; 49,18; 50,40, Lm 4,6; Ez 16,49; Syr 16,8; Mdr 10,6; Mt 10,15; 11,23-24; Mk 6,11; Łk 10,12; 17,29; Rz 9,29; 2 P 2,6; Jud 7, Ap 11,8), tak jak i literatura apokryficzna

1 Por. Springett, Homosexuality in History, 42. Inne opracowania monograficzne, w mniejszym lub większym zakresie wykorzystujące interesujące nas teksty, to np.: McNeil, The Church and the Homosexual; Soards, Scripture and Homosexuality; Brawley (red.), Biblical Ethics and Homosexuality; Gagnon, The Bible and Homosexual Practice. 
(np.: 3 Mch 2,5; Testament Neftalego 3,4-5; Księga Jubileuszów 16,5-9; 20,5-6; Testament Beniamina 9,1; Testament Lewiego 14,6) są doskonałym przykładem jego wagi i nadanych mu treści symbolicznych. Motyw ten przekroczył ramy Biblii i stał się w zachodniej kulturze archetypem niegodziwości i należnej za nią odpłaty.

Opowiadanie z Rdz 19,1-29 nie jest skoncentrowane na charakteryzowaniu szczegółów winy mieszkańców Sodomy i nie rozwija tego tematu. Wina jest przyjęta jako coś oczywistego, co uwidacznia się w procesie narracji. Wcześniejsze wzmianki w Rdz 13,13 lub 18,20 określają tę winę ogólnie jako ciężką. Ma ona jednak zostać zweryfikowana, sprawdzona przez Boga (por. Rdz 18,21). Narracja z Rdz 19,1-29, ukazująca pełne przemocy zachowanie mieszkających w Sodomie mężczyzn, tak wobec przybyłych do miasta gości, jak i Lota, oraz powszechność tej postawy, potwierdza ich winę $e^{2}$.

Obecnie istnieje tendencja do pomijania kwestii homoseksualnej w interpretacjach tego opowiadania. Często skupia się uwagę na temacie naruszenia mocno ugruntowanego w starożytnej kulturze bliskowschodniej prawa gościnności, czyli na zachowaniu pełnym przemocy wobec obcych i usiłowanie ich podporządkowania sobie. Jeśli podejmuje się zagadnienia dotyczące sfery seksualnej, to często podkreśla się tylko temat seksualnej przemocy, o której mowa w opowiadaniu. Istotnie jest to ważna kwestia w w tej perykopie, co nie oznacza jednak, że temat negatywnej oceny zachowań homoseksualnych powinien zostać odrzucony ${ }^{3}$. W tego typu interpretacjach przyjmuje się bowiem często negatywną ocenę gwałtu, ale aktu homoseksualnego już nie. Zdaniem zwolenników tego podejścia w opowiadaniu tym nie ma negatywnego odniesienia do homoseksualizmu jako takiego ${ }^{4}$. Sugerują także, że interpretacjom takich tekstów, jak Jud 7 oraz 2 P 2,6, sięgającym po motyw zniszczenia Sodomy i okolicznych miast, niesłusznie narzuca się egzegezę powiązaną z karą za aktywność homoseksualną.

Rzeczywiście z punktu widzenia wykorzystania tego motywu w Jud 7 i 2 P 2,6 ważne jest zwrócenie uwagi na kilka kwestii, jakich ten tekst dotyka. Powyższy postulat można uznać za słuszny, o ile będzie rozumiany jako konieczność odczytywania całego kontekstu semantycznego, a nie zamiar wykluczenia tematyki homoseksualizmu z egzegezy tych tekstów. W problemie wykorzystania tego motywu w Jud 7 i 2 P 2,6 ważne jest zwrócenie uwagi na kilka kwestii, jakich ten tekst dotyka. W Rdz 19,1-29 mamy bowiem wskazówki, które pozwalają interpretować grzech mieszkańców Sodomy także w znaczeniu zaspokajania homoseksualnej pożądliwo-

2 Por. Wenham, Genesis, 55.

3 Janusz Lemański (Księga Rodzaju, 375), idąc za Billem T. Arnoldem, słusznie zauważa, że takie kierunki w interpretacji tego tekstu w znacznej mierze biorą się z chęci przypodobania się współczesnym trendom, niż z chęci odczytania rzeczywistych sensów tego tekstu.

4 Por. np. Gnuse, „Seven Gay Texts”, 73; http://religiousinstitute.org/denom_statements/homosexuality-not-a-sin-not-a-sickness-part-ii-what-the-bible-does-and-does-not-say/ [dostęp: 14.09.2020]; https:// www.hrc.org/resources/what-does-the-bible-say-about-homosexuality/ [dostęp: 14.09.2020]. 
ści między mężczyznami. Przede wszystkim jest to informacja narratora, że starzy i młodzi mężczyźni ze wszystkich stron miasta Sodomy otoczyli dom Lota i domagali się poznania jego gości ( $R d z$ 19,4-5). Słowo „poznać” (od rdzenia jd) jest tu użyte eufemistycznie, jednak w oczywisty sposób sugeruje jego rzeczywisty sens „akt seksualny”. Taką możliwość semantyczną dopełnia bowiem reakcja Lota proponującego zgromadzonym przed domem mężczyznom Sodomy swoje córki, które jeszcze "nie poznały” mężczyzny ${ }^{5}$. Trudno w takim kontekście obstawać przy interpretacji, że chodzi tu tylko o naruszenie i zachowanie prawa gościnności, chociaż jest to kanwą tej narracji. W istocie mamy tu domaganie się umożliwienia aktu gwałtu homoseksualnego. Negatywna ocena wyrażona w karze zagłady Sodomy obejmuje całość takiego żądania. Nie ma wystarczających podstaw do tego, by twierdzić, że wyrok jest efektem potępienia braku gościnności lub zamiaru gwałtu, a sam akt homoseksualny nie jest widziany negatywnie.

W tradycji żydowskiej motyw zniszczenia Sodomy i Gomory bezsprzecznie funkcjonował jako wyrażenie kary Bożej, ale już interpretacje, co do rodzaju grzechu, który był tego przyczyną, były różne ${ }^{6}$. Komentarz egzegetyczny Filona z Aleksandrii, bliski czasowo listom Judy i Piotra, w interpretacji tego fragmentu wyraźnie mówi, że grzechem Sodomitów były homoseksualne akty między mężczyznami, co sprzeciwiało się pierwotnemu zamysłowi i porządkowi ustalonemu przez Boga (De Abrahamo, 135-136). Potwierdza to taką interpretację owego tekstu. Podobną tendencję możemy znaleźć w Testamencie Neftalego 3,4-5, gdzie grzech sodomski uznany jest za świadome przekraczanie ustalonego porządku, nie ma tam wprost wskazania na akty homoseksualne. Adresaci Listów Powszechnych, zwłaszcza Listu św. Judy, znali jednak także inne teksty albo analogiczne tradycje ustne odnoszące się do tego motywu w szerszym kontekście. Są interpretacje, w których nie koncentrowano się w ogóle na praktycznej odsłonie czynów Sodomitów, a zwracano uwagę na ich rzeczywistą przyczynę - pychę i bezbożność (np. jak w Ez 16,49; Syr 16,8; Mdr 10,6; 3 Mch 2,5) lub też rozszerzano je na wszelką rozwiązłość seksualną (np. Księga Jubileuszów 16,5-9, 20,5-6; Testament Beniamina 9,1; Testament Lewiego 14,6)7. W literaturze prorockiej motyw Sodomy często służył do porównania i obrazowania ohydy bałwochwalstwa ${ }^{8}$.

Trudno pominąć fakt, że w biblijnej recepcji motywu Sodomy dominuje sens nieuchronności Bożej kary za niegodziwość, a nie tematyka homoseksualizmu mieszkańców Sodomy ${ }^{9}$. Nie jest to jednak wystarczający powód do uznania, że temat homoseksualizmu w narracji z Rdz 19,1-29 nie istnieje. Niewątpliwym pożytkiem płynącym z tego typu kontestacji dla rozważań nad tematem oceny homoseksuali-

Por. Lemański, Księga Rodzaju, 375.

Por. Webb, „The Use of 'Story' in the Letter of Jude”, 57.

Więcej na temat biblijnych aluzji do motywu Sodomy, jego transformacji i amplifikacji zob. Fields, Sodom and Gomorrah, 155-184.

8 Por. Wolthuis, „Jude and Jewish Tradition”, 28-30.

9 Por. Soards, Scripture and Homosexuality, 16. 
zmu w świetle Biblii jest zwrócenie uwagi na potrzebę podejmowania tych kwestii holistycznie, w ujęciu całego kanonu, a nie z perspektywy jednego tekstu. Natomiast dla naszych rozważań istotne jest to, na ile temat utrzymywania homoseksualnych kontaktów, związany z opowiadaniem z Rdz 19,1-29, znalazł swoje odzwierciedlenie w odwołaniu się do motywu Sodomy i Gomory przez autorów Listów Powszechnych.

\subsection{Funkcja motywu Sodomy i Gomory w Liście św. Judy}

W Liście św. Judy motyw Sodomy i Gomory nie jest samodzielnie rozwijany, nie jest też punktem wyjścia do jakiś rozważań, co nie znaczy, że ma znaczenie marginalne. Pojawia się w rozdziale 7 i jest częścią dłuższej wypowiedzi dotyczącej bliżej nieokreślonych bezbożnych (asebeis), stanowiąc jeden z elementów definicji owej postawy $\mathrm{i}$ tego, co się $\mathrm{z}$ nią wiąże ${ }^{10}$. Zanim przejdziemy do charakterystyki postawy owych asebeis, jaką wnosi motyw Sodomy i Gomory, przyjrzyjmy się podstawowym zarzutom wobec nich.

Autor listu mówi o nich już na samym początku, w wersecie 4, definiując powód swojego wystąpienia. Ich obecność i działalność pośród członków wspólnoty rozpoznał jako prawdziwe zagrożenie dla całej wspólnoty, co stało się powodem napisania listu. W wersecie 4 wskazuje na dwie cechy charakteryzujące postawę bezbożnych: pierwszą z nich jest zamienianie łaski Boga na „zuchwałość”, „pychę”, „rozwiązłośc”, „wyuzdanie” (aselgeia). Drugą zaś - odrzucanie jedynego Władcy i Pana naszego Jezusa Chrystusa. Określenia te są połączone spójnikiem współrzędnym „i” (kai), co pozwala rozumieć je z jednej strony niezależnie od siebie, to znaczy, że ową zuchwałością czy rozwiązłością nie jest samo odrzucanie Chrystusa, ale wyraża to coś więcej, jakieś inne czyny lub postępowanie. $Z$ drugiej strony nie są to cechy rozłączne, a to znaczy, że postawa tej zuchwałości lub rozwiązłości, cokolwiek by one oznaczały, ściśle wiąże się z tym, czym jest odrzucanie autorytetu Jezusa Chrystusa.

Dla współczesnego odbiorcy zarzuty te są nieco enigmatyczne i rodzą pewnego rodzaju niejasności ze względu na brak znajomości realnego kontekstu tej wypowiedzi, z czym nie musieli się borykać bezpośredni adresaci Listu św. Judy. Komentatorzy uważają, że zamienianie łaski na rozwiązłosć i odrzucanie jedynego Władcy i Pana naszego Jezusa Chrystusa może wyrażać stan bycia ochrzczonym, przy jednoczesnym pozostawaniu w dawnym stylu życia, to znaczy, że mowa jest o ludziach, którzy przyjęli wiarę i chrzest, ale później, przez uparte trwanie w grzechu i uniewinnianie go według własnych zasad, ich zachowanie stało się w rezultacie postawą wewnętrznego odrzucenia Boga ${ }^{11}$. Przyjęcie stanu łaski jest w słownictwie chrześcijańskim równoznaczne z uznaniem Jezusa jako Pana i Zbawiciela, który poniósł śmierć za grzeszników, odkupiając winy (zob. np. Rz 4,5; 5,6.10-11). Jednak świado-

\footnotetext{
10 Por. Brosend, James and Jude, 170.

11 Por. Harrington, 1 Peter, Jude and 2 Peter, 190.
} 
mość uzyskania daru zbawienia często prowadziła do błędnego pojmowania swojego życia w kategoriach swobody postępowania. Podłożem tej wypowiedzi może być więc także sytuacja powoływania się na uzyskaną łaskę zbawienia, aby uprawomocniać swoje grzeszne czyny ${ }^{12}$. Charakteryzujące postawę bezbożnych określenie „zamieniania łaski Pana na rozwiązłość" przypomina ocenę Pawła Apostoła z Rz 1,25, gdzie mówi on o bezbożnych (asebeis), którzy „prawdę Boga zamienili na kłamstwo”. Kontekstem tej wypowiedzi jest między innymi opis niezgodnych z Bożą wolą zachowań w sferze seksualnej, w tym aktywnej homoseksualności mężczyzn i kobiet (zob. Rz 1,26-27). Znajomość listów św. Pawła wśród odbiorców Listu św. Judy mogła być czytelną wskazówką, do jakiej sytuacji we wspólnocie odnosi się autor. Podobieństwo to jednak jednoznacznie o tym nie przesądza.

Pojawiające się sformułowanie o odrzucaniu Jezusa Chrystusa jako Władcy i Pana zdaje się być klarowne i sugeruje, że chodzi o jakichś jawnych przeciwników wyznawców Chrystusa. Jednak ci, o których mówi autor, to nie ludzie atakujący wspólnotę z zewnątrz, ale będący wewnątrz niej, co zdecydowanie powinno wykluczać taką postawę. Na pojawienie się tychże bezbożnych we wspólnocie w wersecie 4 użyty został czasownik pareisedysan w formie aorystu, oznaczający „przeniknięcie”, „wślizgnięcie się gdzieš”, „przedostanie się”. Autor, używając tego określenia, z jednej strony podkreśla, że nie chodzi o coś hipotetycznego, ale o fakt, który już się dokonał (owi ludzie rzeczywiście są we wspólnocie), a zarazem wyraża swój stosunek do tych ludzi, sugerując podstępność ich działania. Dalsze wypowiedzi autora na temat bezbożnych (w. 12) potwierdzają, że nie jest to tylko subiektywna ocena autora, który rozpoznając potencjalny problem, zbudował sytuację retoryczną swojej wypowiedzi dla przeprowadzenia argumentacji. Autor mówi bowiem w dalszej części listu wprost, że owi ludzie współuczestniczą w agapach i ocenia ich udział jednoznacznie negatywnie, demaskując ich bezbożnośćc ${ }^{13}$. W wersetach 12-13 występuje seria asyndetycznie połączonych metafor, opisujących tych bezbożnych. Pierwsza z nich, spilades, oparta jest na metonimii, niesie ze sobą kilka możliwych znaczeń: są oni tymi, którzy niosą ze sobą zniszczenie; tymi, którzy wprowadzają nieczystość; tymi, którzy rozbijają jedność wspólnoty. Wynika to z możliwości tłumaczenia słowa spilas jako „nawałnica”, „burza”, „skaza”, „plama”, „pęknięcie”, „wyrwa”. Trudno jest ocenić, na czym konkretnie polegało zagrożenie sprowadzane na wspólnotę. Mogło się wiązać z zawoalowanym odrzucaniem autorytetu władzy Jezusa Chrystusa, które polegało na hołdowaniu własnym przekonaniom i skłanianiu innych do akceptacji takiej postawy. Możliwe też jest, że przekonania i zachowania ludzi, nazwanych przez autora bezbożnymi, mogły być przejmowane przez

\footnotetext{
12 Por. Green, Jude and 2 Peter, 60.

13 Por. Green, Jude and 2 Peter, 57.
} 
pozostałych członków wspólnoty, którzy nie dostrzegali w ich postawach sprzeciwiania się autorytetowi Boga ${ }^{14}$.

Drugą niejasnością jest to, co autor Listu św. Judy miał na uwadze, gdy przypisując bezbożnym pychę, zuchwałość lub rozwiązłość, posłużył się pojęciem aselgeia o dużej pojemności semantycznej. Pomocą w rozumieniu tych zarzutów jest charakterystycznie skonstruowana argumentacja (ww. 5-7 oraz 11), której siła przekonywania opiera się na przykładach zaczerpniętych z Pisma Świętego i z tradycji pozakanonicznej. Interesujący nas tu szczególnie motyw Sodomy i Gomory buduje tę argumentację, wieńcząc jej pierwszą część (ww. 5-7) z podsumowaniem w wersecie 8.

Odwołanie do motywu zniszczenia Sodomy i Gomory oraz okolicznych miast nie zostało szczególnie rozbudowane. Jest trzecim w serii odniesień. Poprzedza je przykład wytraconych niewierzących podczas wędrówki po pustyni po wyjściu z Egiptu oraz sprzeniewierzonych aniołów, uwięzionych na dzień Sądu Bożego. Każdy z tych przykładów, obok wiodącej myśli o Bożym sądzie i karze, wnosi dodatkowe, własne sensy. Wśród podstawowych można wymienić: 1) to, że Bóg jest tym, który wyzwala i ratuje, nie oznacza, że będzie tolerował zło wśród tych, których ocalił (Jud 5); 2) władza Boga obejmuje cały świat stworzony, widzialny i niewidzialny dla ludzkich zmysłów; 3) władza Boga jest ponad czasem (Jud 6); 4) Bóg jest Panem, do którego należy sąd, ocalenie i kara za grzech (Jud 7) ${ }^{15}$. Nie jest to bez znaczenia także dla właściwego rozumienia użycia przykładu zniszczenia Sodomy. Wszystkie trzy egzemplifikacje łączy jedna, podstawowa kategoria - nieuchronnej kary Bożej, jaka spotyka tych, którzy sprzeciwiają się zamysłom Boga i postępują niegodziwie. Jest to istotna myśl całego Listu św. Judy, który koncentruje się na idei sądu Bożego, ale także interesującym nas motywie Sodomy i Gomory.

Lakoniczność wypowiedzi w przywołanych w Liście św. Judy przykładach można uznać za nieco ryzykowną strategię perswazji. Może to bowiem przyczyniać się do nadinterpretacji lub błędnych interpretacji zamysłu jego autora. Treść argumentacji, zwłaszcza dla odbiorcy niezaznajomionego z materiałem egzemplifikującym, tak co do jego źródeł, jak i tradycji interpretacji, może być trudna do zrozumienia, a na pewno nie pozwala na odkrycie pełnego bogactwa treści i siły perswazji ukrytej w argumentacji ${ }^{16}$. Autor jednak wśród przewidywanych odbiorców zakładał znajomość materiału, do którego się odwoływał, a także tradycji jego odczytywania, czego świadectwem może być formuła otwierająca argumentację: „Chcę wam przypomnieć, wam wiedzącym wszystko [...]" (w. 5a $)^{17}$. W tej sytuacji przyjęcie wysokiego poziomu uogólnienia w odniesieniach do źródeł jest świadomym działaniem autora, pozwa-

\footnotetext{
14 Por. Davids, The Letters of 2 Peter and Jude, 69-70; Reese, 2 Peter and Jude, 41.

15 Por. Brosend, James and Jude, 170.

16 Nie jest dla współczesnych czytelników Listu św. Judy oczywiste, do jakich tekstów konkretnie autor się odwołuje.

17 Por. Green, Jude and 2 Peter, 63.
} 
lającym na wprowadzenie do argumentacji wielu możliwych znaczeń i interpretacji związanych z przywołanymi przykładami. Autor celowo nie ogranicza się do jednego konkretnego tekstu źródłowego albo jednej z interpretacji wykorzystanych przykładów. Z punktu widzenia perswazyjności tekstu jest to bardzo ważne, bo angażuje intelektualnie i emocjonalnie odbiorcę. Przykłady te mogą oddziaływać bardzo silnie przy uwzględnieniu wpływu całego możliwego wachlarza kontekstów, jakie ze sobą niosą. Najprawdopodobniej motywy te były dobrze utrwalone w tradycji ustnego nauczania w synagogach. Znane były adresatom nie tylko teksty źródłowe tychże motywów, ale także ich najważniejsze interpretacje, zawarte w innych tekstach i w tradycji oralnej. Analogiczny zestaw przykładów występuje w Syr 16,6-8 i 3 Mch 2,4-7, podobne (podawane w innej kolejności) w Misznie (traktat Sanhedrin 10,3). Zwraca się w nich uwagę na nieuchronność Bożej kary za popełniane niegodziwości ${ }^{18}$. Dlatego przykłady zawarte w Liście św. Judy mogły pozostać nierozwinięte i co do szczegółów niewyjaśnione.

W samym odwołaniu się do motywu zniszczenia Sodomy i Gomory w Liście św. Judy 7 mamy jednak formę odautorskiego komentarza, precyzującego sens i wskazującego na rodzaj winy zarzucanej bezbożnym, o których mówi autor listu. Za komentarz ten można uznać dopowiedzenie o zniszczeniu innych miast, których mieszkańcy postępowali w sposób analogiczny do mieszkańców Sodomy i Gomory. Podobieństwo to autor oddaje dwoma określeniami, kluczowymi dla zrozumienia jego interpretacji przykładu. Pierwszym jest ekporneusasai „uprawianie nierządu”, określenie pojawiające się w formie imiesłowu aorystu, które w Nowym Testamencie występuje tylko w tym miejscu. Słowo to w sensie podstawowym (porneuō) oznacza podejmowanie niewłaściwych zachowań seksualnych, bycie rozwiązłym seksualnie, uprawianie prostytucji, cudzołożenie, a w metaforycznym (LXX) jest używane jako synonim oddawania czci bóstwom. Tekst źródłowy tego przykładu, jakim jest opowiadanie z Rdz 19,1-29, nie wzmiankuje wprost o bałwochwalczych kultach Sodomitów. Nie ma więc podstaw do przyjmowania w pierwszej kolejności metaforycznego sensu tego terminu w Jud 7. Drugim określeniem-komentarzem jest zdanie, które wyraża „podążanie za drugim ciałem” (dosł. apelthousai opisō sarkos heteras) - idiom oznaczający praktyki seksualne niezgodne z naturą, przekraczające ustalone grani$\mathrm{ce}^{19}$. Wielu komentatorów słusznie zwraca uwagę, że nie ma tu mowy wprost o relacjach homoseksualnych. Przeciwnie, użyte słowo heteros („drugi”, „inny”, „różny”) wskazywać by mogło na relacje heteroseksualne lub na seksualne pożądanie jako takie, bez rozróżniania płci lub przedmiotu tego pożądania ${ }^{20}$. Niektórzy jednak zauważają, że idiom ten koresponduje z wcześniejszym przykładem, odwołującym się do aniołów, którzy sprzeciwili się woli Boga i porzucili swoją czysto duchową natu-

\footnotetext{
18 Por. Rowston, „The Most Neglected Book”, 558; Moo, 2 Peter and Jude, 247-248.

19 Por. Bauckham, Jude - 2 Peter, 54.

20 Por. np. Davids, The Letters of 2 Peter and Jude, 52; Mickiewicz, List św. Judy, 92.
} 
rę, podejmując współżycie seksualne z kobietami (Rdz 6,1-4). Odczytując sens tego idiomu w kontekście argumentu, w jakim został użyty, można go potraktować jako figurę retoryczną wykorzystującą antytezę i analogię. Podobieństwo przebiegałoby na linii nieposłuszeństwa wobec porządku zamierzonego wolą Boga: aniołowie - negujący i odrzucający zadania wyznaczone im w dziele stworzonego świata; mieszkańcy Sodomy - negujący swoim postępowaniem zasady i prawa dla zaspokojenia swoich żądz; bezbożni (asebeis) - odrzucający autorytet władzy Jezusa Chrystusa i podążający za spełnianiem własnych pożądliwości ${ }^{21}$. Przeciwieństwo natomiast sprowadza się do przeciwstawienia sobie pożądania aniołów, pragnących ludzkiego, kobiecego ciała i mieszkańców Sodomy, pożądających seksualnego aktu z aniołami ${ }^{22}$.

Obydwa wyrażenia komentujące odwołanie się do motywu sodomskiego odnoszą się do kontekstu seksualnych zachowań. Problem wspólnoty mógł więc dotyczyć nadużyć w tej kwestii, skoro autor kieruje uwagę odbiorców listu na powiązaną z tym motywem sferę seksualną i na tę linię interpretacji. Posłużenie się przykładem Sodomy i Gomory oraz negatywna ocena obecności i udziału osób postępujących w sposób jawnie niegodziwy w ucztach eucharystycznych (w. 12), o czym już była mowa wcześniej, wskazują na to, że zachowania te w jakiś sposób musiały być dopuszczane i akceptowane przez wspólnotę. Jest więc prawdopodobne, że owi bezbożni, jak ich nazywa autor listu, próbowali nadać swojemu postępowaniu rangę zachowań uprawnionych i być może udało im się przekonać do tego część członków wspólnoty ${ }^{23}$. W wersecie 8 nazwani są bowiem „śniącymi” (enypniadzomenoi), co oznacza, że mogli się oni odwoływać do posiadanego wyższego poznania na podstawie umiejętności odczytywania snów lub doświadczania wizji, ekstaz prorockich i w ten sposób wprowadzać fałszywe nauki oparte na ich własnych poglądach ${ }^{24}$. Możliwe jest także, że autor - wybierając przykład Sodomy - chciał zwrócić uwagę odbiorców na ostentacyjność postępowania bezbożnych, która jest analogiczna do powszechnego, niegodziwego i pozbawionego zahamowań zachowania mieszkańców Sodomy ${ }^{25}$.

Ten komentarz autora przypomina odbiorcom głównie, że kara dla Sodomy i Gomory nie jest wyjątkiem, że dotyczyła nie tylko mieszkańców tych miast, ale wszystkich, którzy w podobny sposób postępowali (homoios tropos). Zagłada widziana jest więc przede wszystkim jako forma ostrzeżenia przed wszystkimi analogicznymi przypadkami zuchwałego grzeszenia ${ }^{26}$. Przestroga ta wbrew pozorom nie jest skierowana do bezbożnych, do których autor ani razu wprost się nie zwraca, ale do adresatów listu, nazywanych przez niego powołanymi i umiłowanymi. To wskazuje, że w opinii autor listu byli oni w niebezpieczeństwie współudziału w niegodziwym

21 Por. Neyrey, 2 Peter, Jude, 61.

22 Por. np. Bauckham, Jude - 2 Peter, 54; Watson, Invention, Arrangement, and Style, 53.

23 Więcej na ten temat zob. Wolthuis, „An Analysis of the Book of Jude”, 291.

24 Por. Desjardins, „The Portrayal of the Dissidents”, 93-94.

25 Por. Charles, „'Those' and 'These”, 115.

26 Por. Mickiewicz, List św. Judy, 92-93. 
postępowaniu, dlatego na tym skoncentrował swoją argumentację, nie zaś na szczegółowym analizowaniu, udowadnianiu i wykazywaniu winy bezbożnych. Uwidacznia to jeszcze bardziej werset 8 , gdzie autor, komentując postępowanie bezbożnych, tworzy bardzo charakterystyczną strukturę porównania (homoiōs mentoi) przez zestawienie trzech rzeczy adekwatnie przypisanych do każdego z trzech użytych wcześniej przykładów.
A: niewierzący na pustyni (w. 5)
C': hańbią ciało (w. 8a)
B: sprzeniewierzeni aniołowie (w. 6)
B': odrzucają autorytet (w. 8b)
C: rozwiązłość Sodomy i Gomory (w. 7)
A’: bluźnią Chwałom (w. 8c)

Ponownie autor listu potwierdza, że postawa bezbożnych, przed którą ostrzega wspólnotę, jest prawdziwym duchowym zagrożeniem, ma podłoże natury nie tylko moralnej, ale i duchowej, i wynika $\mathrm{z}$ ignorowania Boga, przeciwstawienia się autorytetowi Jego władzy, braku pełnego zaufania i zawierzenia Bogu, co w rezultacie prowadzi do zachowań niegodziwych, sprzecznych z Jego wolą, fałszywych. Odnosi się to tylko w jakiejś części do niewłaściwych zachowań seksualnych, które mogły być jednym z rozpoznawalnych przejawów tej wewnętrznej postawy bezbożności, jaka zrodziła się pośród wspólnoty. Zarzut plugawienia czy też hańbienia ciała (sarka miainousin) jest dość jednoznaczny, nawet jeśli został wyrażony eufemistycznie. Chociaż może także odnosić się do rzeczywistości znacznie szerszej, to znaczy, że autor ciało rozumiał w sensie chrześcijańskim jako miejsce spotkania $z$ Bogiem, Jego świątynię. Wówczas każdy grzech, a nie tylko grzech w sferze ludzkiej seksualności, byłby aktem hańbienia ciała. Takie rozumienie tego wyrażenia również dobrze koresponduje z zarzutem bezbożności wobec tych, którzy są pośród wspólnoty. Czy więc za podstawę przywołania motywu Sodomy i Gomory, dopowiadającego komentarza (Jud 7) i sformułowania oceny postępowania bezbożnych (Jud 8) można uznać praktykowanie aktów homoseksualnych, albo czy odbiorcy listu tak właśnie mogli rozumieć te wypowiedzi autora?

Zwróćmy uwagę, że pierwotni adresaci Listu św. Judy po pierwsze wiedzieli do czego w ich kontekście nawiązuje autor, po drugie, znając dobrze tekst źródłowy, mogli przykładać takie rozumienie do wykorzystującej motyw Sodomy i Gomory wypowiedzi autora listu i dzięki temu właściwie rozpoznawać przestrzeń skierowanego ostrzeżenia. Znali też bez wątpienia zarówno to, jak reinterpretowany był ów motyw w samej Biblii oraz jak był wykorzystywany w szerszej tradycji religijnej, w tekstach pozakanonicznych i ustnym nauczaniu. Wszystkie te interpretacje motywu Sodomy i Gomory oddziaływały na adresatów w sposób mniej lub bardziej uświadomiony i sprzyjały temu, by bez wątpliwości mogli ocenić zachowania - charakteryzowanych przez autora listu - bezbożnych w ich wspólnocie. Pod takim wpływem bogactwa tradycji interpretacyjnych był też i sam autor. Niemożliwe jest jedno- 
znaczne stwierdzenie, że autor listu, posługując się motywem zniszczenia Sodomy i Gomory, wskazywał, że winą bezbożnych były w szczególności praktyki homoseksualne. W żaden sposób też ich nie wykluczył, podobnie jak i szersze interpretacje opowiadania z Księgi Rodzaju znane z tradycji pozakanonicznej. Może to świadczyć o tym, że zarzut wobec bezbożnych obejmował także utrzymywanie związków homoseksualnych, ale nie homoseksualność była rzeczywistym powodem argumentacji i wystąpienia autora Listu św. Judy. Wspólnota, która funkcjonowała w środowisku kultury hellenistycznej z pewnością miała do czynienia z przenikaniem takich zachowań. Autor listu nie rozwinął szczególnie tej kwestii przede wszystkim dlatego, że widział wszelkiego typu niemoralne zachowania w sferze seksualnej jako coś wtórnego, tzn. jako efekt postawy, która w rzeczywistości jest odrzuceniem Boga, takim jakim On jest, i usiłowania kreowania Go na własne wyobrażenie. To właśnie uznawał on za prawdziwy problem wspólnoty i powód do „walki o wiarę” (Jud 3). Problem nadużyć w sferze seksualnej rozważał więc w szerszym kontekście. Pewne jest, że autor - wybierając motyw zniszczenia Sodomy, który posłużył mu głównie do wyakcentowania tego, że Boży sąd i kara dotyczą każdego grzesznika - zwrócił jednocześnie uwagę, że sfera ludzkiej seksualności nie zostaje wykluczona spod władzy Boga i nie może być traktowana jako przestrzeń zależna od woli człowieka oraz jego ludzkich przekonań i osądów. Stosunek Listu św. Judy do praktykowania aktów homoseksualnych można uznać za jednoznaczny właśnie ze względu na rozważania, które koncentrują się na analizie duchowych zagrożeń, na motywacji skłaniającej do przyjmowania lub akceptowania praktyki zachowań homoseksualnych. Nic w Liście św. Judy nie wskazuje, aby nauczanie w zakresie seksualności, w tym i relacji homoseksualnych, w jakikolwiek sposób różniło się od tego, co można znaleźć na ten temat w tradycji biblijnej, tam gdzie podejmowano tę kwestię partykularnie i jednoznacznie.

\subsection{Motyw Sodomy i Gomory w Drugim Liście św. Piotra}

W 2 P 2,6, podobnie jak w Liście św. Judy, mamy odwołanie do motywu Sodomy i Gomory. Nie jest jednak pewne, czy adresatom Drugiego Listu św. Piotra także znana była dobrze treść opowiadania biblijnego, tradycja jego interpretacji i recepcji, i czy te tradycje literackie i pozaliterackie, wnosząc swoje konotacje, stanowiły adekwatną siłę retorycznego oddziaływania na odbiorcó $w^{27}$. Podobieństwo wykorzystania tego motywu w Drugim Liście św. Piotra jest uderzające. Pojawia się on w mowie (2,122) mającej charakter ostrzeżenia adresatów przed zgubną działalnością pośród wierzących jakiś bliżej nienazwanych fałszywych nauczycieli (pseudodidaskaloi), którzy zwodzić będą wierzących. Autor w 2 P 2,2 przypisuje im postawę pychy, zuchwałości czy też rozpusty, rozwiązłości, posługując się dokładnie tym samym terminem asel-

Por. Davids, The Letters of 2 Peter and Jude, 129. 
geia, co autor Listu św. Judy. Analogii do tego i zawartej w nim argumentacji w jest 2 P 2,2 tak dużo, że wielu komentatorów opowiada się za zależnością Drugiego Listu św. Piotra od Listu św. Judy ${ }^{28}$. Przyjrzyjmy się ewidentnym podobieństwom. Przede wszystkim, tak jak w Liście św. Judy, chodzi o zwodnicze postępowanie jakiś ludzi, którzy są wewnątrz społeczności wierzących, a nie atakują z zewnątrz (2 P 2,1). Ponadto zarzuty wobec tej grupy to między innymi negowanie władzy Jezusa, zuchwała pycha i rozwiązłość, bluźnierstwa i pogarda wobec bytów anielskich (2 P 2,1.10.12). Podobnie też motyw Sodomy i Gomory jest trzecim w serii przykładów, chociaż ich lista nie pokrywa się całkowicie z serią z Jud 5-7. Nie wystarcza to jednak, aby uznać, że chodzi o taką samą grupę osób, reprezentującą adekwatny katalog win, jaki został rozpoznany przez autora Listu św. Judy u bezbożnych, których miał na myśli. Pomimo licznych analogii można zaobserwować także różnice w wykorzystaniu motywu Sodomy, co może wynikać $\mathrm{z}$ odmiennego zakorzenienia adresatów, $\mathrm{z}$ innego podłoża problemów we wspólnocie i ich kontekstu albo też być efektem przyjęcia innej strategii perswazyjnej, dostosowanej do sytuacji i odbiorców.

Warto natomiast zwrócić uwagę na to, że wykorzystanie treści Listu św. Judy w części argumentacji Drugiego Listu św. Piotra rzuca światło na to, jak interpretowano w tym czasie List św. Judy. Odniesieniami do niego autor Drugiego Listu św. Piotra posługuje się w oczywisty sposób w tej części argumentacji, która obnaża postępowanie fałszywych nauczycieli, w tym ich rozwiązłość seksualną. Być może więc to, co dla współczesnego odbiorcy nie jest już takie oczywiste i rodzi problemy interpretacyjne, wśród chrześcijan z I wieku nie pozostawiało wątpliwości, a kontekst seksualnych nadużyć poruszony w Liście św. Judy był bezdyskusyjny.

Wykorzystując odwołanie się do zniszczenia Sodomy w 2 P 2,6 autor jeszcze bardziej niż autor Listu św. Judy podkreśla, że skazanie na zagładę, obrócenie w popiół Sodomy i Gomory jest przykładem (hypodeigma) zapowiadającym los bezbożnych (asebeis). Przede wszystkim nie przypomina on o zagładzie innych miast sąsiadujących z Sodomą i Gomorą ani też nie mówi o podobieństwie winy ich mieszkańców. Poprzedza ten przykład odwołaniem się do kary dla sprzeniewierzonych aniołów, strąconych do otchłani, gdzie czekają na sąd (co przypomina drugi z przykładów w serii z Jud 6), oraz odwołaniem się do kary potopu zesłanego na świat bezbożnych za dni Noego ${ }^{29}$. Ponadto wzmacnia tę kolekcję przykładów antytetycznymi narracjami o ocalonych sprawiedliwych (Noem i Locie). Komentatorzy Drugiego Listu św. Piotra zwracają uwagę na istotność kontekstu wypowiedzi związanych z działal-

28 Liczne analogie stały się przedmiotem długiej dyskusji, próbującej rozstrzygnąć, któremu z listów należy przyznać status hypotekstu. Jedni dowodzili, że autor Listu św. Judy korzystał z Drugiego Listu św. Piotra, inni dowodzili stanowisko przeciwne. Więcej na ten temat zob. Thurén, „The Relationship Between 2 Peter and Jude”, 451-460; Mathews, „The Literary Relationship of 2 Peter and Jude”, 47-66.

29 Analogiczne zestawienie sądu potopu i zniszczenia Sodomy oraz ocalenia Noego i Lota i ich rodzin mamy także u Łk 17,26-30, co może wskazywać, że były to popularne przykłady w nauczaniu na temat Bożego sądu, być może często używane przez samego Jezusa w czasie nauczania. 
nością fałszywych nauczycieli we wspólnocie wierzących, którym było wypaczanie nauki o paruzji Chrystusa. O ile w przypadku bezbożnych z Listu św. Judy można powiedzieć, że najprawdopodobniej oni sami odwoływali się do wyższego poznania, jakie posiadają, to w przypadku fałszywych nauczycieli z Drugiego Listu św. Piotra można przypuszczać, że mogli oni mieć status nauczycieli, tym bardziej więc głoszone przez nich nauki i zachowanie były realnym zagrożeniem dla wiary i zbawienia także pozostałych wierzących ${ }^{30}$. Z dalszej treści listu (3,3-10) wynika, że negowali oni sam fakt nastąpienia paruzji, a także władzy Jezusa, któremu powierzono sąd nad całym światem stworzonym. Dlatego też uwaga autora w tych trzech przykładach skupia się zdecydowanie bardziej na sądzie jako akcie Boga, który ocala sprawiedliwych, a niegodziwych unicestwia, niż na charakterystyce postępowania bezbożnych. W kategoriach kulturowych można to uznać za odpowiedź na wyzwanie wobec honoru Boga-Suwerena ${ }^{31}$. Sposób przywołania przez autora motywu zniszczenia Sodomy i Gomory uwidacznia jego cele perswazyjne. Wykorzystując obrazowość motywu ich zniszczenia, ukazując je jako miasta obrócone w popiól, co podkreśla ich unicestwienie, eksponuje ideę sądu podczas paruzji i całkowitego zniszczenia zła w czasach eschatologicznych ${ }^{32}$. Natomiast przez komentarz, że stało się to widocznym przykładem tego, co spotka bezbożnych, akcentuje, że pełnia Bożego sądu i kary nastąpi podczas paruzji, będzie miała wymiar całkowity i nie ominie nikogo, kto źle postępuje. Wprowadzenie przykładu ocalonych sprawiedliwych (2 P 2,5-8), Noego i Lota, których postawa jest przeciwieństwem nastawienia bezbożnych fałszywych nauczycieli, jeszcze bardziej skupia uwagę odbiorców na działaniu Boga reagującego na postępowanie ludzi. Sąd Boży ukazywany jest jako nieuchronny i sprawiedliwy, niepozwalający na zniszczenie prawych razem z niegodziwymi (2 P 2,9).

Z punktu widzenia naszego tematu należy powiedzieć, że sama obecność motywu Sodomy i Gomory w serii przykładów nie wnosi głównie informacji co do natury winy fałszywych nauczycieli. Nie ma podstaw do tego, by uznać, że autor Drugiego Listu św. Piotra, posługując się motywem Sodomy, miał na celu przede wszystkim wskazanie adresatom na seksualną rozwiązłość lub - jeszcze bardziej zawężając - homoseksualność jako na grzech, przed którym ostrzega adresatów. Z całą pewnością jednak jednoznacznie wyraził konsekwencje, z jakimi wiąże się niegodziwe postępowanie, utrzymując całą wypowiedź w tonie ostrzeżenia.

Takie rozłożenie akcentów w argumentacji mogłoby sugerować, że autor Drugiego Listu św. Piotra kwestię rozwiązłości seksualnej uważał za sprawę drugorzędną. Jednak poświęca on znacznie więcej uwagi tej problematyce niż List św. Judy. Istotną rolę odgrywa tu właśnie rozwinięcie wątku ocalenia Lota i jego rodziny w 2 P 2,7-8, ściśle powiązanego z motywem zniszczenia Sodomy i Gomory. Autor dodaje tu wła-

\footnotetext{
30 Por. Green, „Second Peter Use of the Jude: 'Imitatio”, 13.

31 Por. Neyrey, 2 Peter, Jude, 199.

32 Por. Fields, Sodom and Gomorrah, 136.
} 
sny komentarz, który zdecydowanie można uznać za interpretację motywu ocalenia Lota. Komentarz ten wnosi znacznie więcej treści niż samo opowiadanie biblijne, w którym ocalenie Lota i jego najbliższych prezentowane jest bardziej jako skutek wstawiennictwa Abrahama niż osobistej prawości i sprawiedliwości Lota ${ }^{33}$. Autor używa tu konstrukcji amplifikującego powtórzenia, mającej charakter parentezy w toku dowodzenia, która służy funkcjom emfatycznym (np. w postaci komentarza, wyjaśnienia, wtrąconej narracji) po to, by zaznaczyć, co uznaje się za ważne w logicznym porządku argumentacji. Postępowanie Lota nie jest tylko przeciwstawione zachowaniu pozostałych mieszkańców Sodomy. Sprawiedliwy (dikaion) Lot ukazany jest jako ten, który nie tylko nie naśladował ich postępowania i nie dał się wciągnąć w ich sposób bycia, ale był tym, który doznawał z tego powodu cierpienia, był umęczony (kataponoumenon) z powodu ich zuchwałej rozwiązłości, a jego sprawiedliwa dusza ( $p s y c h \bar{e}$ dikaia) dzień po dniu była torturowana (basanidzō) ich nieprawymi czynami. Od tej duchowej udręki i bezradności wobec rozwiązłości i pychy (aselgeia) mieszkańców Sodomy Lot został wyratowany (errysato) przez Boga.

Taki opis postawy Lota podkreśla moralną i duchową naturę opresji, jakich doznawał, ale nie oznacza, że nie odnosi się do cielesnych, seksualnych zachowań mieszkańców Sodomy ${ }^{34}$. Z jednej strony ten charakterystyczny komentarz autora listu do motywu zniszczenia Sodomy i Gomory oraz ocalenia Lota może być traktowany jako słowa otuchy dla adresatów listu, dające im nadzieję, że zostaną wyrwani z doświadczenia zła, $z$ jakim im przyszło się mierzyć. $Z$ drugiej strony może być uznane za wyraźne wezwanie do naśladowania postawy Lota i braku zewnętrznej i wewnętrznej zgody na dziejące się zło, na rozwiązłość seksualną, jaką próbuje się im narzucać jako normę $e^{35}$.

Seksualny podtekst winy fałszywych nauczycieli podkreślają dalsze wypowiedzi autora listu. W 2 P 2,10b ponownie precyzuje grupę ludzi, którzy będą podlegać nieuchronnej karze w dzień sądu, zestawiając ze sobą dwa elementy ich zachowania: dążenie za „nieczystym”, „zdeformowanym” (miasmos) pożądaniem cielesnym oraz lekceważenie „władzy”, „panowania” (kyriotētos), co można odnieść do słów z 2,1, gdzie mowa była o fałszywych nauczycielach i negowaniu przez nich władzy, tego, który ich wykupił, Jezusa Chrystusa. W 2,13 autor konkluduje, że wyniszczenie bezbożnych jest zapłatą za ich nieprawość, niesprawiedliwość (misthon adikias). Dalszą część wypowiedzi można uznać za wyjaśnienie, o jaką nieprawość chodzi, chociaż zdanie jest niejasne, brzmi idiomatycznie i trudne jest do przetłumaczenia. Sens tej wypowiedzi jest zdecydowanie negatywny, nawet inwektywny, musi więc chodzić

33 Por. Lemański, Księga Rodzaju, 390.

34 Por. Davids, The Letters of Second Peter and Jude, 230.

35 Biorąc pod uwagę, że pojawiające się w komentarzu autora do przywołanego motywu zniszczenia Sodomy słowo hypodeigma - „przykład” często występuje w literaturze parenetycznej, uprawnione jest traktowanie exemplum Lota jako przykład przeciwstawny, do naśladowania. Por. np. Harrington, 1 Peter, Jude and 2 Peter, 267. 
o jakieś przerysowane, naganne zachowania, które autor obnaża ${ }^{36}$. Zarzuca on bezbożnym, że czerpią przyjemność (hēdonē) z rozpusty lub ze zbytków (tryfē) w dzień, że są plamą i hańbą (spiloi kai mōmoi), rozkoszując się lub mając upodobanie (entryfōntes) w ich oszustwach, w zwodzeniu lub w ich rozrywkach (apatais), podczas wspólnego ucztowania (syneuōchoumenoi). Nie jest jasne, o jakie uczty chodzi. Część komentatorów wyklucza tu udział w ucztach eucharystycznych, wskazując, że raczej chodzi o inne wspólne biesiadowanie ${ }^{37}$. Działania bezbożnych mogły obejmować zarówno sferę słowa - dotyczyć wygłaszania fałszywych nauk, zwodniczych deklaracji, jak i sferę aktów, gestów lub jawnego zachowania („w dzień”), epatowania swoją wielkością, władzą, bogactwem, postawami deprecjonującymi innych oraz seksualną rozwiązłością, zachowaniami, które wykraczały także poza czas samego współucztowania, ale ujawniały się wówczas szczególnie ${ }^{38}$. To, że chodzi także o kontekst seksualny w ich zachowaniach, sugeruje dalsza część wypowiedzi. W 2,14 autor używa bowiem metaforycznej hiperboli, mówiąc, że ich oczy są pełne cudzołożnicy i nieustannie w grzechu. Nieuporządkowane pożądanie seksualne staje się narzędziem pomagającym w upadku moralnym „nieutwierdzonych dusz". Ta sama myśl zostaje powtórzona w sformułowanym w 2,18 zarzucie, że działający we wspólnocie fałszywi nauczyciele bezczelnie głoszą „głupoty” („marności”, „czcze słowa”), to znaczy, że przemawiają w sposób zuchwały, wskazujący na dużą pewność siebie, są bardzo przekonujący, w ten sposób wciągają nieutwierdzonych w zdemoralizowane praktyki seksualne, w rzeczywistości wprowadzając ich w kłamstwo i łamanie Bożego Prawa ${ }^{39}$.

Autor Drugiego Listu św. Piotra nie porusza wprost problematyki aktów homoseksualnych. Podobnie jak w przypadku Listu św. Judy, kontekst opowiadania z Księgi Rodzaju może na to wskazywać, ale w Drugim Liście św. Piotra to przede wszystkim temat sądu Bożego i nieuchronnej kary jest istotny w posłużeniu się motywem zniszczenia Sodomy i Gomory. Motyw ten jest podporządkowany strategii zdyskredytowania działalności fałszywych nauczycieli, którzy zaprzeczali prawdzie o Bożym sądzie - było to podstawą ich fałszywego głoszenia, sprowadzającego na manowce nieutwierdzonych. Głosili oni „wolność” od zobowiązań prawa moralnego, wyznaczając mu samodzielnie granice, pozostając jednocześnie w niewoli swoich pożądliwości, których pomimo przyjęcia wiary w Chrystusa, nie chcieli odrzucić

36 Por. Mickiewicz, List św. Judy, 287.

37 Por. Reese, 2 Peter and Jude, 156. Kontekstem dla tej wypowiedzi mogło być uczestniczenie przez tych, którzy przyjęli chrześcijaństwo w okazyjnych ucztach związanych z życiem codziennym społeczności pogan, której częścią pozostawali. Nie chodzi o to, że autor za naganny uznawał sam udział w takich spotkaniach. Chodziło raczej o przyjmowanie stylu zachowania, jaki był preferowany lub akceptowany, gdzie nie brakowało zachowań rozwiązłych seksualnie. Tego typu dwulicowość była antyświadectwem dla wielu nowo ochrzczonych.

38 Por. Bauckham, Jude - 2 Peter, 269-270; Green, Jude and 2 Peter, 278-280.

39 Kontekstem dla tej wypowiedzi może być przenoszenie na wspólne ucztowanie chrześcijan zachowań przyjętych i uznawanych za pewien element przynależny ucztom pogańskim, które stawały się miejscem seksualnego zaspokojenia. Por. np. Green, Jude and 2 Peter, 281. 
(2,19-20). Fałszywe głoszenie oraz upowszechnianie seksualnej rozwiązłości było źródłem upadku i antyświadectwem chrześcijańskiego życia. Autor, jeśli obejmował w swoim nauczaniu także akty homoseksualne, to nie zostały one potraktowane w sposób wyjątkowy, ale włączone we wszelkie niemoralne zachowania seksualne, które nie są zgodne z Bożym Prawem i są w związku z tym jednoznacznie ocenione jako podlegające Bożej karze.

\section{Kwestia homoseksualna w Apokalipsie św. Jana}

W Apokalipsie św. Jana mamy cztery teksty z określeniami, które w interpretacjach są odnoszone do zachowań homoseksualnych lub których pole semantyczne obejmuje także i takie zachowania ${ }^{40}$. Pierwszym jest Ap 9,20-21, gdzie autor mówi o czynach, od których się ludzie nie odwrócili pomimo zesłanych na ludzkość kar. Kolejne trzy teksty to zawierające listy ludzkich postaw i czynów, które wykluczają ludzi ze społeczności zbawionych: Ap 21,8.27; 22,15.

Kontekst bezpośredni tych fragmentów jest różny, stąd forma pojawiających się wyliczeń podyktowana jest retoryką wypowiedzi danego fragmentu. Treść list nie jest identyczna. Nie pokrywają się ani co do zawartości, ani co do kolejności wymienianych grzechów. Żadna z nich nie ma na celu całościowego ujęcia problematyki powodów wykluczenia ani wyliczenia wszystkich wad, czynów i postaw, które są podstawą niemożności posiadania udziału w zbawieniu ${ }^{41}$. Paralelne zestawienia tych wyliczeń i porównania co do znaczenia chronologii poszczególnych określeń $\mathrm{w}$ danych listach nie znajdują więc uzasadnienia ${ }^{42}$. Najbardziej zbliżone w zakresie zawartości i obszerności są listy z Ap 21,8 i 22,15, co może wynikać z podobieństwa kontekstu wypowiedzi: w pierwszym przypadku mowa jest o tych, którzy nie będą mieć udziału ze Zwycięzcą, lecz przewidziane jest dla nich ,jezioro ognia i siarki”; w drugim - mamy do czynienia $\mathrm{z}$ listą tych, którzy nie mogą zamieszkać w Nowej Jerozolimie i pozostaną na zewnątrz jej murów ${ }^{43}$. Warto natomiast zwrócić uwagę na podobne do list z Apokalipsy, znajdujące się w Corpus Paulinum (zwłaszcza Rz 1,26-32; 1 Kor 6,9-10), katalogi grzechów, które uniemożliwiają odziedziczenie

40 Por. Springett, Homosexuality in History, 49.

41 Por. Wojciechowski, Apokalipsa świętego Jana, 376.

42 W komentarzach można się spotkać ze sformułowaniami, że w danej liście konkretne określenie zastępuje inne, z innej listy, tylko na podstawie miejsca w kolejności wyliczenia, co błędnie sugeruje jakiś rodzaj hierarchizacji porządku poszczególnych określeń albo ich synonimicznej semantyki. Por. np. Goundry, Commentary on the New Testament, 1071.

43 Hypotekstem dla takiej koncepcji mogą być listy z Pwt 18,9-14, gdzie wymieniane są zakazy dla Izraela dotyczące powielania określonych zachowań i czynów pogan po wejściu do ziemi obietnicy. 
królestwa Bożego i które powodują śmierć. Apostoł mówi w nich wprost o praktykach homoseksualnych, określając je jako przeciwne naturze (Rz 1,26-27 i 1 Kor 6,9).

Ap 9,20-21

którzy się nie nawrócili i nie przestali

kłaniać się demonom i sporządzanym

bożkom [bałwochwalcy]

którzy nie odwrócili się od zabójstw

którzy nie odwrócili się od czarów

którzy nie odwrócili się od rozwiązłości

którzy nie odwrócili się od kradzieży

Ap 21,8
tchórze
niewierzący
czyniący ohydztwa
mordercy
rozpustnicy
czarownicy
bałwochwalcy
kłamcy

Ap 21,27

wszystko, co jest psy

nieczyste

czyniący ohydę

czyniący kłamstwo

czarownicy

rozpustnicy

zabójcy

bałwochwalcy

miłujący i czyniący

kłamstwo

Pojawiające się w tych wyliczeniach w Apokalipsie św. Jana terminy, które są interpretowane w odniesieniu do homoseksualizmu, to przede wszystkim: porneia („rozpusta”, „nierząd”) i kyōn („pies”), ale również „ohyda” i „nieczystość”. Żaden z tych terminów wprost nie oznacza ani skłonności, ani praktyk homoseksualnych.

Słowo porneia występuje w kilku znaczeniach. W sensie ogólnym odnosi się przede wszystkim do sfery seksualnej człowieka, oznaczając rozpustę, rozwiązłość, cudzołóstwo, nieczystość moralną. W znaczeniu technicznym używane jest na określenie prostytucji, uprawiania nierządu, zarówno w odniesieniu do kobiet, jak i mężczyzn. Występuje także w sensie metaforycznym na określenie bałwochwalstwa (w LXX), oddawania czci bożkom, głównie, gdy wykorzystuje się obrazowość wpisaną w to słowo, aby ukazać kontrast pomiędzy prawdziwą wiarą i czcią Prawdziwego i Jedynego Boga a fałszywą wiarą i kultem bóstw, które są pochodną ludzkich wyobrażeń i pragnień.

W Ap 9,21 kontekst wskazuje na możliwe dwojakie znaczenie słowa porneia ogólne, i metaforyczne. Poprzedza je bowiem $(9,20)$ peryfraza odnosząca się do postawy bałwochwalstwa. Zestawienie więc czterech określeń ludzkich czynów i zachowań (zabójstwo, uprawianie czarów lub trucicielstwo oraz kradzież) może być kontynuacją peryfrazy albo też (co wydaje się bardziej uzasadnione) przykładowym wyliczeniem cech charakteryzujących postępowanie ludzi tkwiących w rzeczywistości w błędzie bałwochwalstwa ${ }^{44}$. Można tu dostrzec analogię do Dekalogu ${ }^{45}$. Podobnie zgubne skutki bałwochwalstwa wylicza np. autor Księgi Mądrości (14,22-27).

\footnotetext{
44 Niektórzy interpretują rozpoczynające werset Ap 9,21 kai w znaczeniu addytywnym, tj. jako „także”, „też", wprowadzając tym samym pewnego rodzaju semantyczne rozgraniczenie pomiędzy treścią w 9,20 a 9,21. Por. np. przekład Piotra Ostańskiego (Objawienie Jezusa Chrystusa, 194) oraz przekład w: Pismo Święte Starego i Nowego Testamentu. Najnowszy przekład z języków oryginalnych $z$ komentarzem (Częstochowa: Edycja Świętego Pawła 2008).

45 Por. Wojciechowski, Apokalipsa świętego Jana, 243.
} 
W Ap 9,20-21 mowa jest o tym, że pomimo doświadczenia strasznych wydarzeń, niszczących znaczną część ludzkości, nadal pozostali tacy ludzie, którzy nie zmienili swojego postępowania, nie dostrzegli związku pomiędzy tym, co się dzieje, a swoimi czynami i nie przylgnęli do prawdziwego Boga ${ }^{46}$. To pozwala rozumieć, że to, co określane jest tu jako porneia, ostatecznie jest wyrazem postawy bałwochwalczej, kiedy przedkłada się zaspokajanie własnych pożądliwości ponad Boga. Nawet jeśli autor nie użył w tym miejscu słowa porneia jako metonimii bałwochwalstwa, to jednoznacznie wskazał na związek tych rzeczywistości, bo nieporzucenie rozwiązłości w sferze seksualnej (ponieważ autor jej nie precyzuje, to można uznać, że każdej, czegokolwiek by ona nie dotyczyła) ostatecznie zostało zaliczone do postawy sprzeciwiającej się Bogu. Jest to podobne do myśli Pawłowej z Rz 1,20-28, gdzie apostoł wyjaśnia konsekwencje nieuznawania Boga i nieokazania Mu czci, pokazując, że takie postępowanie wobec Boga wypacza człowieka także w sferze seksualnej i może prowadzić do hołdowania praktykom homoseksualnym.

Dwa kolejne fragmenty, gdzie występuje termin porneia, Ap 21,8 oraz 22,15, dotyczą opisu rzeczywistości zbawczej i zawierają listy tych, którzy nie będą mieć w tym udziału. W obydwu przypadkach katalogi te są pod względem gramatycznym typową parataksą, tzn. wymieniane elementy są równorzędne, nie są sobie podporządkowane. Nie oznacza to jednak, że nie mogą mieć pokrewnego znaczenia. Interesujący nas termin występuje tu w formie rzeczownika l. mn. pornoi, które można tłumaczyć jako „rozwiąźli”, „rozpustnicy”, ponieważ w katalogach tych pada niesąsiadujące bezpośrednio określenie eidōlolatrai „bałwochwalcy”, co sugeruje możliwe semantyczne rozgraniczenie tych określeń, to znaczy, że w tym wypadku pornoi nie zastępuje słowa „bałwochwalcy”. W tym wypadku autor posłużył się więc słowem pornoi w sensie ogólnym, mając na myśli wszystkich tych, którzy dopuszczają się nadużyć w sferze seksualnej, odróżniając je od bałwochwalstwa. Trzeba przy tym przyjąć cały wachlarz pola semantycznego, ponieważ nie mamy żadnej wskazówki, która pozwalałaby na jakieś ograniczenie i doprecyzowanie. Trudno jest bowiem stwierdzić, czy w tym miejscu autor ma na myśli wszelkie formy rozwiązłości seksualnej, czy konkretne, jak np. prostytucja, męska prostytucja, prostytucja sakralna. Nie przesądza też o tym, że mowa jest tu w sposób szczególny o homoseksualistach, co jednak wcale nie oznacza, że należy pominąć takie znaczenie. Autor nie pozostawia natomiast wątpliwości, co do oceny owych niewłaściwych zachowań seksualnych. Obydwa katalogi mają charakter wykluczający, w Ap 21,8 winni mają udział w „śmierci drugiej”, natomiast w 22,15 są tymi, którzy pozostają „,na zewnątrz”, poza murami Nowej Jerozolimy, symbolizującej rzeczywistość zbawienia, i nie są w stanie już zagrozić tym, którzy są wewnątrz miasta.

Skoro autor Apokalipsy św. Jana nie redefiniuje w żaden sposób pojęcia porneia ani nie precyzuje swojej wypowiedzi, nawet w ramach możliwości gatunku literac-

Por. Ostański, Objawienie Jezusa Chrystusa, 194. 
kiego, który pozwalałby na przykład na szczegółowe wyliczenie czynów, postaw i zachowań seksualnych, przed którymi autor pragnąłby ostrzec swoich odbiorców, to może to oznaczać, że bazuje on na funkcjonującym w biblijnej tradycji, przyjętym rozumieniu tego, co w zachowaniach seksualnych człowieka jest, a co nie jest właściwe, to znaczy zgodne z Bożym zamysłem. Oczywiście pozostaje kwestią otwartą to, jaką świadomość tego mieli domniemani odbiorcy, zważywszy na pogańską proweniencję chrześcijan, którzy wyrastali i żyli w społecznościach, w których ocena moralna wielu zachowań seksualnych, na przykład stosunków homoseksualnych, nie była negatywna (o czym świadczą doskonale np. List do Rzymian i Pierwszy List do Koryntian), a także w niewielu sytuacjach była sankcjonowana prawnie.

Drugie z określeń odnoszonych w interpretacjach Apokalipsy św. Jana do zachowań homoseksualnych to kynes ",psy”, występujące tylko w katalogu w Ap 22,15. Podstawę do takich interpretacji daje znaczenie, w jakim posługiwano się tym słowem. Określenie to $\mathrm{w}$ większości przekładów oddawane jest dosłownie, co w dyskursie publicznym na temat religijnej oceny homoseksualizmu budzi kontrowersje i oskarżenia, że Biblia promuje język inwektywny, obraźliwy wobec osób homoseksualnych. W jakiś sposób świadczy to o tym, że słowo to jest rozumiane jako określenie osób homoseksualnych. Czy rzeczywiście autor Apokalipsy św. Jana użył tego słowa w takim właśnie znaczeniu?

W języku greckim dosłownie rzeczownik kyōn oznaczał psa lub sukę, o czym decydował użyty rodzajnik. W sensie figuratywnym posługiwano się tym słowem w różnych znaczeniach w odniesieniu do ludzi, zarówno w pozytywnym, jak i w pejoratywnym tonie (np. znaczenie „stróż”, „opiekun” mogło brzmieć i pozytywnie, i negatywnie, ale już zdecydowanie pogardliwie brzmiało ono, kiedy było użyte w stosunku do kobiet i mężczyzn, podkreślając ich pozbawione wstydu postępowanie). Tłumacze LXX w Pwt 23,19 posłużyli się tym słowem w zakazie składania w domu Pana ofiary pochodzącej z zapłaty za nierząd, bo dla Boga jest to ohydą. Jest tam wyraźne rozgraniczenie wskazujące, że chodzi zarówno o prostytucję kobiet, jak i mężczyzn. Przetłumaczono słowem kyōn hebrajskie keleb („pies”), które mogło funkcjonować jako techniczne określenie na prostytuującego się mężczyznę, ale mogło też być pejoratywną formą wypowiedzi, wyrażającą dezaprobatę dla tego typu zachowań ${ }^{47}$. Ponieważ w zakazie poprzedzającym (Pwt 23,18) mowa jest o sakralnej prostytucji, która jest pośród ludu Izraela niedopuszczona zarówno w żeńskim, jak i męskim wydaniu, to niekiedy ogranicza się przenośny sens słowa „pies” do nierządu sakralnego świadczonego przez mężczyzn, a nie męskiej prostytucji jako takiej.

W kulturze Bliskiego Wschodu termin „pies” używany w stosunku do ludzi także, tak jak w kulturze greckiej, nie zawsze niósł negatywne konotacje, bo wyra- 
żano nim lojalność, oddanie, uległość, wierność w powierzonym stróżowaniu nad czymś lub kimś, usłużność ${ }^{48}$.

Przenośna semantyka słowa „psy” w kulturze judaizmu ewoluowała, rozszerzając swój zakres. Może to być pochodną myślenia o psach jako zwierzętach nieczystych, zjadających truchło, a nawet ludzkie szczątki ${ }^{49}$. W kulturze śródziemnomorskiej pierwszego wieku słowo „pies” było także określeniem ludzi głupich, którzy niewolniczo dążą do zaspokojenia swoich namiętności ${ }^{50}$. Słowem tym nazywano ludzi postępujących niemoralnie, nie ograniczając się tylko do prostytucji czy do nieczystości seksualnej w ogóle. ${ }^{51}$ Żydzi używali tego określenia, mówiąc o poganach jako tych, którzy nie mają udziału w świętości wybranego narodu. W takim sensie było ono synonimiczne w stosunku do słowa „nieczysty”, także w znaczeniu nieczystości rytualnej, wykluczającej z kultu ${ }^{52}$. Echo takiego sensu odróżniającego, separującego od narodu wybranego możemy zobaczyć np. w przysłowiu przywołanym przez Jezusa w odpowiedzi na prośbę kobiety kananejskiej, proszącej o uwolnienie jej córki spod władzy złego ducha (Mt 15,26; Mk 7,27-28). Recepcję chrześcijańską tego określenia w analogicznym sensie spotykamy w Didache 9,5 , gdzie w zaleceniach dotyczących udziału w Eucharystii wyraźnie pada zastrzeżenie, że nie powinni jej spożywać nieochrzczeni, a na potwierdzenie takiej zasady zostają przytoczone słowa Jezusa z Mt 7,6 „Nie dawajcie psom tego, co święte”. W Flp 3,2 mamy natomiast użycie tego słowa w szerszym sensie, w znaczeniu niegodziwości, sprzeciwiania się Bożym zamysłom. Paweł bowiem używa tego określenia, opisując postawę tzw. judaizujących, z uporem domagających się od członków wspólnot chrześcijańskich zachowania stosowanych dotąd obrzędów i rytuałów (np. obrzezanie) jako znaku przynależności do Boga, negując tym samym znaczenie i wartość przyjętego chrztu ${ }^{53}$.

Oczywiste jest, że słowo „psy”, otwierające w Ap 22, 15 katalog tych, którzy nie dostąpią zbawienia, ma zdecydowanie negatywny wydźwięk. Trudno jednak o równie jednoznaczne wnioski co do zakresu semantycznego tego słowa w tym kontekście.

Przyjmując, że mamy do czynienia z wyliczeniem, i to znajdującym się w końcowej części księgi, zasadne jest założenie możliwie szerokiego sensu. Czyli „psy” to ludzie postępujący świadomie niemoralnie, nieetycznie, niegodziwi w oczach Boga, bo postępujący wbrew Niemu, bez wskazywania, czego konkretnie owa niegodziwość miałaby dotyczyć.

Nie bez znaczenia jest liturgiczny kontekst tej listy, który sugeruje potencjalne ograniczenie semantyczne określenia „psy”. Autor poprzedza bowiem to wyliczenie o charakterze anatemy wizją kultu „twarzą w twarz” (Ap 22,4), jaki będzie oddawany

\footnotetext{
48 Szeroko na temat tego terminu traktuje J. Lemański („Negatywny obraz psa w Biblii”, 51-96).

49 Por. Aune, Revelation 17-22, 1223.

50 Por. Williamson, Revelation, 366.

51 Por. Springett, Homosexuality in History, 49-50.

52 Por. Aune, Revelation 17-22, 1223.

53 Por. Kistemaker, Exposition of the Book of Revelation, 591.
} 
Bogu w „zstępującym od Boga mieście świętym Jeruzalem” (Ap 21,10), w którym nie mogą mieć udziału ci, którzy nie wypłukali swoich szat we krwi Baranka $(22,14)^{54}$. Ten kontekst pozwala na sprecyzowanie sensu użytego w tym miejscu słowa „psy”. Naturalnie nasuwa się znaczenie „nieczyści”, tzn. niegodni uczestnictwa w Eucharystii, per analogiam do pogan niemogących uczestniczyć w kulcie świątynnym w Jerozolimie. Nie chodzi jednak o ten poziom analogii, który sugerowałby, że nieochrzczeni wykluczeni są z dzieła zbawienia. Ów kontekst liturgiczny nie tyle bowiem zawęża semantykę słowa „psy” do konkretnej grupy ludzi i ściśle określonych zachowań, co podkreśla aspekt skutku, z jakim wiąże się pozostawanie w takiej postawie. „Psami” nazwana by więc była kategoria ludzi trwających świadomie w grzechu, którzy sami pozbawiają się zbawczych darów płynących z Eucharystii. Analogia, jaką wnosi kontekst liturgiczny, przebiega na linii udział w Eucharystii - udział w liturgii oddawania Bogu chwały w niebiańskim Jeruzalem. Chodzi o taką samą sytuację odrzucenia uczestnictwa w łasce przebywania z Bogiem.

Nic nie wskazuje wprost na to, aby autor, używając słowa „psy”, miał na myśli w sposób szczególny męską prostytucję lub praktyki homoseksualne. Na tej samej liście pojawia się także określenie pornoi, wprowadzające znaczenie nadużyć w sferze seksualnej, co wyjaśnione zostało powyżej. Skoro jedno i drugie słowo może odnosić się w pierwszym rzędzie do sfery seksualnej, zasadne jest postawienie pytania o ich semantyczną różnicę, nawet jeśli przyjmiemy, że są one tu synonimiczne w zakresie określania niewłaściwych zachowań seksualnych. Można więc rozumieć tu kynes jako wskazanie na konkretny typ zachowania seksualnego, analogiczny lub różny od pornoi. Określenia te, wyliczone współrzędnie, nie sąsiadują bezpośrednio ze sobą, rozdziela je kategoria tych, którzy uprawiają czary. Trudno więc wnioskować, że słowa te celowo wzajemnie się wyjaśniają, precyzując znaczenie, w jakim są zastosowane. Możliwe jest jednak, że jedno z określeń miałoby na celu wyrażenie prostytucji (kynes), zgodnie ze swoim pierwotnym figuratywnym znaczeniem, a drugie - np. cudzołóstwa (pornoi), na zasadzie eliminacji znaczenia wcześniej wyrażonego innym słowem (w tym wypadku kynes). Jest to jednak arbitralny wybór, który nie wynika z kontekstu. Równie uzasadnionym wyborem bowiem, a może nawet bardziej zasadnym, byłoby przyjęcie szerokiego znaczenia: „niegodziwi” (pełniący wszelkiego typu czyny sprzeciwiające się woli Boga) oraz „rozpustnicy” lub „rozwiąźli” (pełniący w sferze seksualnej czyny, które są niezgodne z wolą Boga). Obydwa określenia przyjmowałby szeroki zakres znaczeniowy, ale w tym wypadku treść słowa pornoi mieściłaby się w zakresie pola semantycznego słowa kynes ${ }^{55}$.

54 Por. Kozyra, „Eschatologia”, 259.

55 Peter Williamson (Revelation, 365) przyjmuje, że określenie „psy” w Ap 22,15 ma sens ogólny przenośny (niegodziwych ludzi) i stanowi słowo kluczowe, nadrzędne, obejmujące sobą wszystkie wymienione dalej kategorie win. 
Nie ma podstaw, aby z zakresu pola semantycznego obydwu tych słów, postawionych w tym konkretnym kontekście, można było wyeliminować znaczenie „homoseksualizm”. Zachowania homoseksualne od początku były postrzegane w chrześcijaństwie jako sprzeczne z Bożą wolą, co dobitnie zostało przedstawione w pismach Pawła Apostoła, a co było bez wątpienia podyktowane potrzebą wspólnot, do których kierował swoje pouczenia. Poświadcza to istniejący wśród chrześcijan wywodzących się z pogaństwa problem ze zrozumieniem powodów odrzucenia dotychczasowego stylu życia także w sferze prywatnej, jak zachowania seksualne. Trudno jest wykazać, że z takim samym dylematem mamy do czynienia w przypadku tekstu z Ap 22,15, ale nie ma wątpliwości, że wówczas osoby utrzymujące stosunki homoseksualne można było określić jako kynes i pornoi, bo adekwatna jest tu zarówno semantyka „niegodziwych”, „nieczystych” (kynes), jak i „rozpustnych”, „wyuzdanych”, „rozwiązłych". Ponadto nie można pominąć tego, że kontekst liturgiczny wystąpienia tych słów w Ap 22,15 i konotacje, jakie przynosi, stosuje się do obydwu tych określeń. I jedna i druga postawa rodzi takie same skutki, pozbawia udziału w łasce przebywania z Bogiem i w obecnej, i przyszłej rzeczywistości. Jeśli więc kontekst nie pozwala na precyzyjne uszczegółowienie semantyki użytych słów, a dodaje do obydwu nowy sens, najbardziej zasadne jest zachowanie w interpretacjach tych pojęć możliwie szerokiego ich znaczenia, z podkreśleniem negatywnych skutków, jakie są następstwem wszelkiego typu zachowania przypisanego tym słowom ${ }^{56}$.

\section{Podsumowanie}

Problem w interpretacji tekstów z Listu św. Judy, Drugiego Listu św. Piotra oraz Apokalipsy św. Jana w kontekście tematyki homoseksualności rodzi się z pytania o to, co w kontekście powstawania tych tekstów, a także obecnie należy uznać za nadużycie, przekroczenie natury, respektowanej normy oraz poszanowania Bożego prawa. Teksty te bezpośrednio bowiem nie podejmują kwestii aktów homoseksualnych ani ich moralnej oceny. Nie rozpatrują homoseksualizmu ani w kategoriach wariantywności ludzkiej seksualności, ani w kategoriach podejmowania aktywności homoseksualnej. Przyjmują szerszą perspektywę, dotyczącą seksualności człowieka, którą ściśle podporządkowują Bożemu zamysłowi, zastrzegającemu tę sferę ludzkiego życia dla małżeństwa pojmowanego jako związek mężczyzny i kobiety. W tym zakresie, w odniesieniu do tych tekstów, homoseksualność może być oceniana z perspektywy

56 Podobnie uważa np. Michał Wojciechowski (Apokalipsa świętego Jana, 397-398), który twierdzi, że przyjęcie szerokiego sensu słowa "psy” eliminuje ewentualne powtórzenie znaczenia męskiej prostytucji w słowie pornoi, opowiada się jednak za zawężeniem semantyki słowa pornoi i unikaniu tłumaczenia go szerszym znaczeniowo „rozpustnicy”. 
podejmowania aktywności seksualnej z osobami tej samej płci, a nie z perspektywy posiadania takiej skłonności.

Nauczanie zawarte w analizowanych tekstach jest pochodną problemów, z jakimi mierzyły się wspólnoty młodego Kościoła oraz pierwotni adresaci wszystkich tych trzech pism. Bez względu na pochodzenie wiernych, wspólnoty chrześcijańskie rozwijały się w kulturze hellenistycznej i nie mogły być wolne od wpływów przekonań, obyczajów i praktyk, które stały w sprzeczności z przyjętym przez nie systemem wartości, wynikającym z wiary w Jezusa jako Jedynego Pana i Zbawiciela. Podjęcie aktu wiary w Jezusa, zwłaszcza przez ludzi wywodzących się z pogaństwa, zazwyczaj wiązało się z radykalną zmianą życia i dotychczasowych obyczajów, co w praktyce mogło być trudne oraz podważane jako konieczne. Wiemy, że w kulturze greckiej i rzymskiej wielu zachowań seksualnych nie uznawano za niewłaściwe lub były one akceptowane, nawet jeśli nie praktykowano ich powszechnie (np. prostytucja, cudzołóstwo, kazirodztwo, pederastia i akty homoseksualne). Nie było to jednoznaczne $\mathrm{z}$ uprawomocnieniem takich relacji ${ }^{57}$. Chrześcijanie, zwłaszcza proweniencji pogańskiej, mogli mieć problem zarówno z odmienną oceną takich zachowań, jak i z porzuceniem dotychczasowych praktyk, judeochrześcijanie mogli zaś pod wpływem fałszywego nauczania odchodzić od przyjętych już wcześniej norm, uznając je za nieaktualne.

Z punktu widzenia naszego tematu ważne jest zwrócenie uwagi na to, że teksty te wpisują się w dyskurs, którego celem było ustalanie granic decydujących o chrześcijańskiej tożsamości. To, co jest uderzające w analizowanych tekstach, to uznanie pełnej władzy Boga w Jezusie, zarówno w wymiarze doczesnym, jak i w eschatologicznym. Na tym zasadza się cała argumentacja tych fragmentów, chociaż za każdym z nich stoi inny kontekst wypowiedzi i sytuacji.

W Liście św. Judy można wskazać, że nauczanie obejmuje także tematykę homoseksualności ze względu na możliwe echa, jakie uruchamiało przywołanie motywu Sodomy i Gomory. Każdy odbiorca Listu św. Judy, który analogicznie do jego pierwotnych adresatów miał dobrą znajomość tradycji kanonicznej i pozakanonicznej, mógł, jeśli tego wymagała sytuacja, dokonać oceny tego, czy akt homoseksualny jest zgodny z Bożym zamysłem. Autor listu jednak w niewielkim zakresie koncentruje się w ogóle na kwestiach konkretnych nadużyć lub nieprawidłowości moralnych, bo jego uwaga zwrócona jest na to, aby naprawiać podstawę - właściwą relację do Boga, nie zaś korygować partykularne zachowania, które autor listu uważa już za konsekwencję rzeczywistej, wewnętrznej negacji tej relacji. Motyw grzeszności mieszkańców Sodomy i Gomory oraz okolicznych miast służy w Liście św. Judy wyeksponowaniu problemu rozwiązłości seksualnej jako przejawu postawy bezbożności.

57 Więcej na temat homoseksualizmu w kulturze greckiej i rzymskiej zob. np. Dover, Greek Homosexuality; Williams, Roman Homosexuality. 
Drugi List św. Piotra ze wszystkich analizowanych tekstów najwięcej uwagi poświęca grzechom w sferze seksualności. Tematyka rozwiązłości seksualnej, będąca tłem wypowiedzi, jest oczywista. Wyeksponowaniu tej problematyki w argumentacji służy jednak motyw cierpienia i ocalenia Lota, dużo bardziej niż sam motyw zniszczenia Sodomy i Gomory, którego zasadniczym celem w argumentacji jest wskazanie na niepozostawiającą wątpliwości rzeczywistość sądu Bożego i kary za bezbożność. Pomimo ewidentnych konotacji dotyczących zachowania w sferze seksualnej Drugi List św. Piotra nie zajmuje się w szczególny sposób tematyką homoseksualności.

W Apokalipsie św. Jana zagadnienia związane z oceną aktów homoseksualnych również nie są bezpośrednio podejmowane, ale można przyjąć, że zostają wpisane w negatywną ocenę zachowań seksualnych, które nie są zgodne z Bożym zamysłem. Pojęcia odnoszące się do utrzymywania rozwiązłości w sferze seksualnej, które pojawiają się w kontekstach oceniających je, jednoznacznie w sposób negatywny, wskazujący na wykluczenie z przebywania z Bogiem, można uznać za wystarczającą wskazówkę do tego, jak należy rozpatrywać kwestię homoseksualnych aktów w świetle przesłania tego utworu.

\section{Bibliografia}

Aune, D.E., Revelation 17-22 (WBC 52C; Grand Rapids, MI: Zondervan 1998).

Bauckham, R., Jude - 2 Peter (The Word Biblical Commentary 50; Grand Rapids, MI: Zondervan 1983).

Brawley, R.L. (red.), Biblical Ethics and Homosexuality. Listening to Scripture (Louisville, KY: Westminster John Knox 1996).

Brosend, W.F., James and Jude (Cambridge: Cambridge University Press 2004).

Charles, J.D., "Those' and 'These': The Use of the Old Testament in the Epistle of Jude”, Journal for the Study of the New Testament 38 (1990) 109-124.

Davids, P.H., The Letters of 2 Peter and Jude (The Pillar New Testament Commentary; Grand Rapids, MI: Eerdmans 2006).

Desjardins, M., „,The Portrayal of the Dissidents in 2 Peter and Jude: Does It Tell Us More About the 'Godly' than the 'Ungodly'?', Journal for the Study of the New Testament 30 (1987) 89-102.

Dover, K.J., Greek Homosexuality (London - Oxford - New York: Bloomsbury 2018).

Fields, W.W., Sodom and Gomorrah. History and Motif in Biblical Narrative (Journal for the Study of the Old Testament Supplement Series 231; Sheffield: Sheffield Academic Press 1997).

Gagnon, R.A.J., The Bible and Homosexual Practice. Texts and Hermeneutics (Nashville, TN: Abingdon Press 2001).

Gnuse, R.K., „Seven Gay Texts: Biblical Passages Used to Condemn Homosexuality”, Biblical Theology Bulletin 45/2 (2015) 68-87.

Goundry, R.H., Commentary on the New Testament. Verse-by-Verse Explanation with a Literal Translation (Peabody: Hendrickson 2010). 
Green, G.L., Jude and 2 Peter (Baker Exegetical Commentary on the New Testament; Grand Rapids, MI: Baker Academic 2008).

Green, G.L., „Second Peter's Use of Jude: Imitatio and the Sociology of Early Christianity”, Reading Second Peter with New Eyes. Methodological Reassessments of the Letter of Second Peter (red. R.L. Webb - D.F. Watson) (London: Clark 2010) 1-26.

Harrington, D.J., 1 Peter, Jude and 2 Peter (Sacra Pagina Series 15; Collegeville, MN: Liturgical Press 2003).

Kistemaker, S.J., Exposition of the Book of Revelation (Grand Rapids, MI: Baker Book 2001).

Kozyra, J., „Eschatologia”, Teologia Nowego Testamentu (red. M. Rosik) (TUM: Wrocław 2008) II, 221-263.

Lemański, J., „Negatywny obraz psa w Biblii. Przyczyny i konsekwencje”, Studia Koszalińsko-Kołobrzeskie 1 (2011) 51-96.

Lemański, J., Księga Rodzaju. Rozdziały 11,27-36,43. Wstęp, przekład zoryginału, komentarz (Nowy Komentarz Biblijny. Stary Testament 1/2; Częstochowa: Edycja Świętego Pawła 2014).

Mathews, M.D., „The Literary Relationship of 2 Peter and Jude: Does the Synoptic Tradition Resolve This Synoptic Problem?", Neotestamentica 44/1 (2010) 47-66.

McNeil, J., The Church and the Homosexual (Boston, MA: Beacon Press 1976).

Mickiewicz, F., List św. Judy. Drugi List św. Piotra (Nowy Komentarz Biblijny. Nowy Testament 18; Częstochowa: Edycja Świętego Pawła 2018).

Moo, D.J., 2 Peter and Jude (The NIV Application Commentary; Grand Rapids, MI: Zondervan 1996).

Mounce, R.H., The Book of Revelation (Grand Rapids, MI: Eerdmans 1997).

Neyrey, J.H., 2 Peter, Jude. A New Translation with Introduction and Commentary (Anchor Bible 37c; New Haven: Yale University Press 1993).

Ostański, P., Objawienie Jezusa Chrystusa. Praktyczny komentarz do Apokalipsy (Ząbki: Apostolicum 2005).

Reese, R.A., 2 Peter and Jude (Grand Rapids, MI: Eerdmans 2007).

Rowston, D.J., „The Most Neglected Book in the New Testament”, New Testament Studies 21 (1975) 554-563.

Soards, M.L., Scripture and Homosexuality. Biblical Authority and the Church Today (Westminster, KY: Westminster John Knox 1995).

Springett, R.M., Homosexuality in History and the Scriptures. Some Historical and Biblical Perspectives on Homosexuality (Washington D.C.: Biblical Research Institute 1998).

Thurén, L., „The Relationship Between 2 Peter and Jude. A Classical Problem Resolved?”, The Catholic Epistles and the Tradition (red. J. Schlosser) (Bibliotheca ephemeridum theologicarum Lovaniensium 176; Leuven: Peeters 2004) 451-460.

Watson, D.F., Invention, Arrangement, and Style. Rhetorical Criticism of Jude and 2 Peter (Society of Biblical Literature Dissertation series 104; Atlanta, GA: Scholar Press 1988).

Webb, R.L., „The Use of 'Story' in the Letter of Jude: Rhetorical Strategies of Jude's Narrative Episodes", Journal for the Study of the New Testament 31/1 (2008) 53-87.

Wenham, G.J., Genesis 16-50 (The Word Biblical Commentary 2; Dallas, TX: Word Books 1994).

Williams, C.A., Roman Homosexuality (Oxford: Oxford University Press 2010).

Williamson, P.S., Revelation (Grand Rapids, MI: Baker Academic 2015). 
Wojciechowski, M., Apokalipsa świętego Jana. Objawienie a nie tajemnica (Nowy Komentarz Biblijny. Nowy Testament 20; Częstochowa: Edycja Świętego Pawła 2012).

Wolthuis, T.R., „An Analysis of the Book of Jude in Its Historical Context”, Calvin Theological Journal 18 (1983) 291.

Wolthuis, T.R., „Jude and Jewish Tradition”, Calvin Theological Journal 22 (1987) 21-45. 